\title{
HUBUNGAN TINGKAT PENGETAHUAN TERKAIT POLA MAKAN DAN AKTIVITAS FISIK DENGAN STATUS KADAR GULA DARAH PADA PASIEN DIABETES MELITUS
}

\author{
Nurmujaahida, Devi Rahmadhona, Dyah Purnaning \\ Fakultas Kedokteran Universitas Mataram \\ Email: jidannurmujaahida05@gmail.com
}

\begin{abstract}
Abstrak
Diabetes melitus merupakan kondisi klinis yang menggambarkan gangguan atau penurunan fungsi pankreas dalam menghasilkan insulin yang cukup bagi tubuh. Kurangnya pengetahuan tentang diabetes melitus mempengaruhi kepatuhan pasien dalam penanganan pengobatan. Hal ini memicu Peneliti untuk melakukan penelitian lebih lanjut terkait "Hubungan Tingkat Pengetahuan Terkait Pola Makan dan Aktivitas Fisik Dengan Status Kadar Gula Darah Pada Pasien Diabetes Melitus Di Rumah Sakit Umum Daerah Kota Mataram”. Penelitian ini menggunakan desain cross-sectional. Responden penelitian ini adalah penderita diabetes melitus rawat jalan yang terdaftar April 2021 - Mei 2021 di Rumah SakitnUmum Daerah Kota Mataram. Terdapat hubungan yang bermakna antara tingkat pengetahuan pola makan dengan status kadar gula darah pasien diabetes melitus dengan nilai $\mathrm{p}=0.014<0,05$. Serta terdapat hubungan yang bermakna antara tingkat pengetahuan aktivitas fisik dengan status kadar gula darah pasien diabetes melitus dengan nilai $\mathrm{p}=0.000<0,05$. Terdapat hubungan yang bermakna antara tingkat pengetahuan pola makan dan tingkat pengetahuan aktifitas fisik dengan status kadar gula darah pasien DM .
\end{abstract}

Kata Kunci: Diabetes Melitus, Tingkat Pengetahuan Pola Makan, Tingkat Pengetahuan Aktivitas Fisik, Status Kadar Gula Darah.

\section{Abstract}

Diabetes mellitus is a clinical condition that describes a disturbance or decrease in the function of the pancreas in producing sufficient insulin for the body. Lack of knowledge about diabetes mellitus affects patient compliance in treatment management. This triggered researchers to conduct further research related to "The Relationship of Knowledge Levels Related to Diet and Physical Activity with Blood Sugar Level Status in Diabetes Mellitus Patients at the Mataram City General Hospital". This study used a cross-sectional design. Respondents in this study were outpatient diabetes mellitus patients who were registered April 2021 May 2021 at the Mataram City Regional General Hospital. There is a significant relationship between the level of knowledge of eating patterns with the status of blood sugar levels in patients with diabetes mellitus with $p$ value $=0.014<0.05$. And there is a significant relationship between the level of knowledge of physical

Copyright holder: Nurmujaahida, Devi Rahmadhona, Dyah Purnaning (2022)

DOI : : https://doi.org/10.54543/fusion.v2i02.174

Published by : Rifa Institute 
Nurmujaahida, Devi Rahmadhona, Dyah Purnaning

activity with the status of blood sugar levels in patients with diabetes mellitus with a value of $p=0.000<0.05$. There is a significant relationship between the level of knowledge of eating patterns and the level of knowledge of physical activity with the status of blood sugar levels in DM patients.

Keywords: Diabetes Mellitus, Knowledge Level of Diet, Knowledge Level of Physical Activity, Blood Sugar Level Status.

Diserahkan: 12-01-2022 Diterima: 25-01-2022 Diterbitkan: 20-02-2022

\section{Pendahuluan}

Diabetes melitus (DM) atau yang akrab dikenal dengan sebutan kencing manis oleh masyarakat umum merupakan kondisi klinis yang menggambarkan gangguan fungsi pankreas dalam menghasilkan insulin yang cukup bagi tubuh atau gambaran yang menunjukkan kondisi ketika tubuh tidak dapat menggunakan insulin secara efektif. Diabetes mellitus ditandai dengan tingginya kadar glukosa darah yang disertai oleh gangguan metabolisme karbohidrat, protein dan lemak (Marewa, 2015).

NTB menempati posisi ke 23 dari 34 provinsi di Indonesia berdasarkan data prevalensi DM pada Riskesdas (2018) dengan presentasi 1,6 \% pada tahun 2018 dan mengalami peningkatan jika dibandingkan dengan tahun 2013 (Apriani et al., 2018). Berdasarkan data Dinas Kesehatan Provinsi NTB (2021) jumlah penderita DM terdapat sebanyak 59.606 jiwa dan hanya sekitar 26.482 penderita yang mendapatkan pelayanan DM sesuai dengan standar. Kota mataram menempati posisi ke 7 dari 10 KabupatenKota di NTB dengan jumlah penderita DM sebanyak 3.588 penderita dan hanya sekitar 1.290 penderita atau 36,0 \% masyarakat yang mendapatkan pelayanan sesuai standar (Sulaeman et al., 2021).

Terdapat beberapa faktor yang mempengaruhi peningkatan angka kejadian DM yakni perubahan pola makan masyarakat yang mengikuti perkembangan zaman dari makanan alami menjadi makanan cepat saji yang tinggi akan lemak, garam, gula, serta rendah serat, merupakan salah satu faktor yang mempengaruhi kejadian DM (Chatterjee et al., 2018). Aktivitas fisik yang teratur seperti olahraga dapat membantu membakar kalori tubuh serta ikut andil dalam menurunkan risiko terjadinya kasus DM (Dafriani, 2017).

Pola makan dan aktivitas fisik yang baik ataupun buruk dapat dipengaruhi oleh tingkat pengetahuan pasien karena, pasien memiliki peran serta dalam menangani kasus DM. Kurangnya pengetahuan tentang diabetes melitus mempengaruhi kepatuhan pasien dalam penanganan pengobatan (Nazriati et al., 2018). Hal ini memicu Peneliti untuk melakukan penelitian lebih lanjut terkait "Hubungan Tingkat Pengetahuan Terkait Pola Makan dan Aktivitas Fisik Dengan Status Kadar Gula Darah Pada Pasien Diabetes Melitus Di Rumah Sakit Umum Daerah Kota Mataram”.

\section{Metode Penelitian}

Penelitian ini menggunakan desain cross- sectional. Responden penelitian ini adalah penderita diabetes melitus rawat jalan yang terdaftar pada tanggal 17-31 Mei 2021 di Rumah Sakit Umum Daerah Kota Mataram. Data diambil dengan menggunakan "Kuesioner Penelitian Pola Makan (Pengetahuan) dan Kuesioner Penelitian Aktivitas Fisik 
(Pengetahuan)", sementara data status kadar gula darah di ambil menggunakan data rekam medis.

\section{Hasil Penelitian}

Penelitian ini dilakukan pada pasien pasien diabetes melitus yang sedang melakukan rawat jalan pada poli penyakit dalam I dan II di Rumah Sakit Umum Daerah Kota Mataram, pengambilan data dilakukan pada bulan mei 2021. Kuesioner penelitian ini berbentuk lembar kuesioner, dengan jumlah responden yang mengikuti penelitian ini sebanyak 50 orang.

\section{Karakteristik Responden}

Responden terdiri dari jenis kelamin perempuan dan laki - laki dengan rentang usia 33 tahun hingga 75 tahun.

Tabel 1. Distribusi Responden Penelitian Berdasarkan Angkatan, Jenis Kelamin dan Usia.

\begin{tabular}{ccc}
\hline Karakteristik & $\mathrm{N}$ & $(\%)$ \\
\hline $\begin{array}{c}\text { Total } \\
\text { Jenis }\end{array}$ & 50 & $(100)$ \\
Kelamin & 29 & $(58.0)$ \\
laki-laki & & $(42.0)$ \\
perempuan & 21 & \\
& & \\
Usia & & $(2)$ \\
25-34 tahun & 1 & $(6)$ \\
$35-44$ tahun & 3 & $(22)$ \\
45-54 tahun & 11 & $(44)$ \\
$55-64$ tahun & 22 & $(20)$ \\
65-74 tahun & 10 & $(6)$ \\
$>75$ tahun & 3 & \\
\hline
\end{tabular}

\section{Gambaran Tehnik Pengambilan Glukosa Darah Pada Responden}

Dari 50 responden penelitian yang digunakan dalam penelitian terdapat 21 responden yang menggunakan $\mathrm{HbA1C}, 22$ responden menggunakan tehnik glukosa darah 2 jam PP, dan 7 orang glukosa darah puasa .

Tabel 5.2 Gambaran Tehnik Pengambilan Glukosa Darah Pada Responden

$$
\text { Kedua kuesioner telah diuji validitas dan Tehnik }
$$

Pengambilan Glukosa Darah

Jumlah Responden reliabilitasnya. Kriteria inklusi adalah semua penderita diabetes melitus tipe 2 dengan pemeriksaan glukosa darah. Pada penelitian ini menggunakan uji statistik yang digunakan adalah uji Pearson, dan uji spearman sebagai alternative.

HbA1C 21

Glukosa Darah 2 Jam 23

PP

Glukosa Darah Puasa 6

Total 50 
Nurmujaahida, Devi Rahmadhona, Dyah Purnaning

\section{Gambaran Tingkat Pengetahuan Terkait Pola Makan}

Rerata skor tingkat pengetahuan terkait pola makan responden adalah 19 responden memiliki tingkat pengetahuan terkait pola makan yang baik, 8 responden memiliki tingkat pengetahuan yang cukup, dan terdapat 23 responden memiliki tingkat pengetahuan terkait pola makan yang kurang.

\section{Gambaran Pengetahuan Terkait Aktivitas Fisik}

Berdasarkan hasil penelitian dari 50 responden, hamper sebagian besar responden memiliki tingkat pengetahuan terkait aktivitas fisik yang kurang, yaitu sebanyak 21 responden memiliki tingkat pengetahuan aktivitas fisik kurang, 15 tingkat pengetahuan aktivitas fisik cukup dan sebanyak 14 orang memiliki tingkat pengetahuan aktivitas fisik yang baik.

\section{Gambaran Status Kadar Gula Darah Pasien Diabetes Melitus}

Sebanyak 35 responden meemiliki status kadar gula darah yang tidak terkontrol dan sebanyak 15 responden memiliki status kadar gula darah yang terkontrol dari 50 jumlah responden. Pada penelitian ini menunjukan hasil status kadar gula darah pada pasien diabetes mellitus berdasarkan Tingkat Pengetahuan Pola Makan didapatkan pasien dengan kadar gula darah terkontrol yang memiliki tingkat Pengetahuan Pola Makan kategori Baik sebanyak 9 pasien, kategori cukup sebanyak 3, dan kategori kurang sebanyak 3. Kemudian untuk pasien dengan kadar gula darah tidak terkontrol yang memiliki tingkat Pengetahuan Pola Makan kategori Baik sebanyak 10 pasien, kategori cukup sebanyak 5, dan kategori kurang sebanyak 20.

Hasil status kadar gula darah pada pasien diabetes mellitus berdasarkan Tingkat Pengetahuan Aktivitas Fisik didapatkan pasien dengan kadar gula darah terkontrol yang memiliki tingkat Pengetahuan Aktivitas Fisik kategori Baik sebanyak 12 pasien, kategori cukup sebanyak 2, dan kategori kurang sebanyak 1. Kemudian untuk pasien dengan kadar gula darah tidak terkontrol yang memiliki tingkat Pengetahuan Aktivitas Fisik kategori Baik sebanyak 2 pasien, kategori cukup sebanyak 13, dan kategori kurang sebanyak 20.

Analisis hubungan Pengetahuan Terkait PolaMakan Dan Aktivitas Fisik denganStatus kadar gula darah pasien diabetes melitus

Analisis hubungan Tingkat Pengetahuan Pola Makan dengan Status kadar gula darah pasien diabetes melitus didapatkan nilai $\mathrm{p}=0.014<0,05$ maka disimpulkan terdapat hubungan antara Tingkat Pengetahuan Pola Makan dengan Status kadar gula darah pasien diabetes melitus. Kemudian untuk Tingkat Pengetahuan Aktivitas Fisik dengan Status kadar gula darah pasien diabetes melitus didapatkan nilai $\mathrm{p}=0.000<0,05$ maka disimpulkan terdapat hubungan antara Pengetahuan Aktivitas Fisik dengan Status kadar gula darah pasien diabetes melitus.

\section{Pembahasan}

Gambaran Tingkat Pengetahuan Terkait Pola Makan

Pada penelitian ini di dapatkan hasil rerata skor tingkat pengetahuan terkait pola makan secara umum adalah kurang. Pola makan yang tidak teratur merupakan faktor penyebab meningkatnya kejadian diabetes. Pola makan merupakan upaya yang dilakukan untuk mengontrol jumlah dan jenis makanan yang dikonsumsi guna menjaga kesehatan, mencegah, maupun menyembuhkan penyakit (Nuraini \& Supriatna, 2016). 
Hal ini diperkuat dengan penelitian yang menunjukan bahwa terdapat hubungan yang signifikan terkait tingkat pengetahuan pasien terhadap pola makan. Seseorang dengan tingkat pengetahuan tahu "Know" mampu mengingat kembali suatu materi yang telah diterima sebelumnya, namun berbeda dengan seseorang yang memiliki tingkat pengetahuan tahap aplikasi, pada tahap ini individu mampu menerapkan materi yang telah diterima pada kehidupannya sehari-hari. Sehingga dalam penelitian ini gambaran tingkat pengetahuan responden terkait pola makan termasuk dalam tahap "Tahu" (Widiyoga et al., 2020).

Pengetahuan penderita tentang penyakit DM sangat penting karena pengetahuan akan membawa penderita DM untuk menentukan sikap, berfikir dan berusaha untuk mengelola penyakitnya serta mengontrol gula darah (Vinti, 2015). Rendahnya tingkat pengetahuan akan mempengaruhi pola makan yang dapat menyebabkan peningkatan kadar gula dalam darah, untuk itu salah satu upaya yang dapat dilakukan yaitu dengan memperbaiki pola makan melalui pemilihan makanan yang tepat. Selain itu pengobatan diabetes yang paling utama yaitu mengubah gaya hidup terutama mengatur pola makan yang sehat dan seimbang. Sebenarnya pasien DM banyak yang mengetahui anjuran diet, tetapi banyak pula yang tidak mematuhi dan menerapkannya (Jaramillo et al., 2013).

Pola makan sehat didefinisikan sebagai pola makan dengan perencanaan 3J yaitu jumlah, jenis, dan jadwal makan yang teratur. Pola makan yang tidak sehat menyebabkan tidak adanya keseimbangan antara karbohidrat dan kandungan lain yang dibutuhkan oleh tubuh. Akibatnya kandungan gula di dalam tubuh menjadi tinggi melebihi kapasitas kerja pankreas dan mengakibatkan terjadinya diabetes melitus .

Gambaran Tingkat Pengetahuan Terkait Aktivitas Fisik

Pada penelitian ini didapatkan dari 50 responden terdapat sebanyak 21 (42\%) responden yang memiliki tingkat pengetahuan kurang terkait aktivitas fisik. Aktivitas fisik dapat membantu meningkatkan sensitifitas reseptor insulin dalam mengubah glukosa menjadi energi melalui proses metabolisme. Pada saat melakukan aktivitas fisik glukosa endogen akan ditingkatkan untuk menjaga keseimbangan glukosa di dalam darah sehingga penggunaaan glukosa oleh otot juga akan ikut meningkat. Selain pola makan yang tidak sehat, aktivitas fisik yang kurang juga menjadi faktor predisposisi terjadinya diabetes melitus (Nurayati \& Adriani, 2017). Otot normal yang dalam keadaan istirahat yang diakibatkan oleh kurangnya aktivitas fisik hampir tidak permeabel terhadap glukosa kecuali bila serat otot dirangsang oleh insulin. Peningkatan risiko diabetes melitus pada aktivitas fisik rendah terjadi karena penurunan kontraksi otot yang menyebabkan berkurangnya permeabilitas membran sel terhadap glukosa. Akibatnya terjadi gangguan transfer glukosa ke dalam sel dan berkurangnya respon terhadap insulin yang mengarah pada keadaan resisten dan dapat menimbulkan diabetes melitus (Hariawan et al., 2019).

Aktivitas fisik dapat menurunkan terjadinya resiko diabetes mellitus melalui efek berat badan dan sensitivitas insulin. Seseorang dengan kadar lemak tubuh yang rendah memiliki resiko yang rendah juga untuk menderita diabetes. Selain itu, aktivitas fisik juga terbukti dapat membantu seseorang dengan diabetes untuk mengurangi konsumsi pengobatan dengan insulin maupun non- insulin (Fikasari, 2012).

Hasil ini juga diperkuat dengan penelitian yang dilakukan Wiardani (2009) yang memberikan hasil bahwa sebagian besar penderita diabetes melitus memiliki aktivitas fisik rendah. Aktivitas fisik rendah memiliki resiko diabetes tiga kali lebih besar 
dibandingkan dengan aktivitas fisik tinggi. Penelitian lainnya menyebutkan bahwa orang dengan aktivitas fisik sehari-harinya berat memiliki risiko lebih rendah untuk menderita diabetes melitus dibandingkan dengan orang yang aktivitas fisik sehari-harinya rendah (Trisnawati \& Setyorogo, 2013).

Aktifitas fisik yang dilakukan secara teratur memiliki peran penting dalam pencegahan secara primer dan pengobatan non-farmakologi dikarenakan physical activity dapat menjaga atau mengontrol tinggi badan, berat badan, lipid dalam tubuh, peningkatan kualitas tidur, penurunan kecemasan, dan glukosa darah.

\section{Hubungan Tingkat Pengetahuan Terkait Pola Makan Dan Aktivitas Fisik dengan Status kadar gula darah pasien diabetes melitus}

Pada penelitian ini didapatkan hasil bahwa terdapat hubungan yang bermakna antara Tingkat Pengetahuan Terkait Pola Makan Dan Aktivitas Fisik dengan Status kadar gula darah pasien diabetes melitus. Pengetahuan yang baik tentang DM khususnya DM Tipe 2 akan menjadikan seseorang mempunyai bekal bagaimana memperlakukan dirinya sejak awal seperti mengatur gaya hidup yang sehat, pola makan, aktivitas fisik serta rutin berolahraga (Siregar, 2021).

Pada penelitian ini, kelompok usia terbanyak yang menderita DM yaitu usia 5564 tahun, hal tersebut sejalan dengan penelitian Nurayati dan Adriani (2017) bahwa pada kelompok umur diatas 50 tahun memiliki peluang sebesar 2,61 kali lebih besar menderita diabetes melitus karena menurunnya fungsi organ tubuh yang mengakibatkan terganggunya metabolisme glukosa dan produksi insulin (Fretts et al., 2009).

Hasil penelitian ini diperkuat dengan penelitian yang dilakukan oleh Hariawan et al (2019) didapatkan hasil ada hubungan pola makan dengan kejadian DM ( $\mathrm{p}=0.02)$ dan ada hubungan aktivitas fisik dengan kejadian DM $(\mathrm{p}=0.009)$. Hasil Penelitian ini disimpulkan bahwa ada hubungan gaya hidup (pola makan dan aktivitas fisik) dengan kejadian DM di RSU Provinsi NTB tahun 2013.

Selain itu, penelian ini juga sejalan dengan hasil penelitian Widiyoga, dkk (2020) terdapat hubungan tingkat pengetahuan dengan pengaturan pola makan $(\mathrm{p}=0,000<\alpha=$ $0,01)$ dan tingkat pengetahuan dengan pengaturan physical activity $(\mathrm{p}=0,006<\alpha=0,01)$. Hasil penelitian lain juga menyebutkan bahwa terdapat hubungan yang bermakna antara tingkat pengetahuan dengan pengendalian kadar glukosa darah, ia juga menyatakan bahwa pengetahuan pasien tentang DM merupakan sarana yang dapat membantu penderita menjalankan penanganan diabetes sehingga semakin banyak dan semakin baik pasien DM mengetahui tentang diabetes melitus serta mampu mengubah perilakunya, akan dapat mengendalikan kondisi penyakitnya sehingga ia dapat hidup lebih lama dengan kualitas hidup yang baik. Tingginya kemampuan penderita untuk mengendalikan keinginan dalam melakukan penatalaksanaan Diabetes Melitus dengan teratur mempengaruhi perilaku penderita dalam mengendalikan kadar gula darah, hal ini karena pengetahuan merupakan domain yang sangat penting untuk terbentuknya perilaku seseorang (Perdana et al., 2013).

\section{Kesimpulan}

Berdasarkan penelitian yang dilakukan terhadap 50 responden pada pasien DM di

RSUD Kota Mataram, diketahui bahwa : Dari seluruh responden diperoleh Gambaran Tingkat Pengetahuan Terkait Pola Makan didapatkan $46 \%$ dalam kategori Kurang. 
Gambaran Tingkat Pengetahuan Terkait aktifitas fisik didapatkan 42\% dalam kategori Kurang. Sebagian besar pasien memiliki kadar gula darah yang tidak terkontrol sebanyak $70 \%$ (35 pasien). Hal ini menunjukan bahwa terdapat hubungan yang bermakna antara tingkat pengetahuan pola makan dengan status kadar gula darah pasien DM $(\mathrm{p}=0.014)$, serta terdapat hubungan yang bermakna antara tingkat pengetahuan aktifitas fisik dengan status kadar gula darah pasien DM $(\mathrm{p}=0.00)$. 
Nurmujaahida, Devi Rahmadhona, Dyah Purnaning

\section{BIBLIOGRAFI}

Apriani, B. N., Hadi, I., Warongan, A. W., \& Supriyatna, N. (2018). Efektivitas Konseling dengan Pendekatan Motivational Interviewing Terhadap Penurunan Depresi pada Pasien Post Stroke Depression. Holistic Nursing and Health Science, 1(2), 55-67. Google Scholar

Chatterjee, S., Davies, M. J., Heller, S., Speight, J., Snoek, F. J., \& Khunti, K. (2018). Diabetes structured self-management education programmes: a narrative review and current innovations. The Lancet Diabetes \& Endocrinology, 6(2), 130-142. Google Scholar

Dafriani, P. (2017). Hubungan Pola Makan dan Aktifitas Fisik Terhadap Kejadian Diabetes Melitus di Poliklinik Penyakit Dalam RSUD dr. Rasidin Padang. NERS Jurnal Keperawatan, 13(2), 70-77. Google Scholar

Fikasari, Y. (2012). Hubungan Antara Gaya Hidup Dan Pengetahuan Pasien Mengenai Diabetes Mellitus Dengan Kejadian Penyakit Diabetes Mellitus Tipe 2 Di Rsud Dr. Moewardi. Universitas Muhammadiyah Surakarta. Google Scholar

Fretts, A. M., Howard, B. V, Kriska, A. M., Smith, N. L., Lumley, T., Lee, E. T., Russell, M., \& Siscovick, D. (2009). Physical activity and incident diabetes in American Indians: the Strong Heart Study. American Journal of Epidemiology, 170(5), 632-639. Google Scholar

Hariawan, H., Fathoni, A., \& Purnamawati, D. (2019). Hubungan gaya hidup (pola makan dan aktivitas fisik) dengan kejadian diabetes melitus di Rumah Sakit Umum Provinsi NTB. Jurnal Keperawatan Terpadu (Integrated Nursing Journal), 1(1), 1-7. Google Scholar

Jaramillo, A., Welch, V. A., Ueffing, E., Gruen, R. L., Bragge, P., Lyddiatt, A., \& Tugwell, P. (2013). Prevention and self-management interventions are top priorities for osteoarthritis systematic reviews. Journal of Clinical Epidemiology, 66(5), 503-510. Google Scholar

Marewa, L. W. (2015). Kencing Manis (Diabetes Mellitus) di Sulawesi Selatan. Yayasan Pustaka Obor Indonesia. Google Scholar

Nazriati, E., Pratiwi, D., \& Restuastuti, T. (2018). Pengetahuan pasien diabetes melitus tipe 2 dan hubungannya dengan kepatuhan minum obat di Puskesmas Mandau Kabupaten Bengkalis. Majalah Kedokteran Andalas, 41(2), 59-68. Google Scholar

Nuraini, H. Y., \& Supriatna, R. (2016). Hubungan pola makan, aktivitas fisik dan riwayat penyakit keluarga terhadap diabetes melitus tipe 2. Jurnal Ilmu Kesehatan Masyarakat, 5(1), 5-14. Google Scholar

Nurayati, L., \& Adriani, M. (2017). Hubungan aktifitas fisik dengan kadar gula darah puasa penderita diabetes melitus tipe 2. Amerta Nutrition, 1(2), 80-87. Google Scholar

Perdana, A. A., Ichsan, B., \& Rosyidah, D. U. (2013). Hubungan tingkat pengetahuan tentang penyakit DM dengan pengendalian kadar glukosa darah pada pasien DM Tipe II di RSU PKU Muhammadiyah Surakarta. Biomedika, 5(2). Google Scholar 
Siregar, D. I. S. (2021). Gambaran Tingkat Pengetahuan Tentang Pencegahan diabetes Mellitus Tipe 2 di Man 2 Mandailing Natal. Google Scholar

Sulaeman, R., Irwansyah, I., Sukmawati, S., \& Masadah, M. (2021). Riwayat Penggunaan Kontrasepsi Hormonal Pada Penderita Kanker Payudara. Jurnal Keperawatan Terpadu (Integrated Nursing Journal), 3(1), 10-16. Google Scholar

Trisnawati, S. K., \& Setyorogo, S. (2013). Faktor risiko Kejadian diabetes melitus tipe II di puskesmas kecamatan cengkareng Jakarta Barat Tahun 2012. Jurnal Ilmiah Kesehatan, 5(1), 6-11. Google Scholar

Vinti, D. (2015). Hubungan Pengetahuan, Sikap dan Kepatuhan Diet dengan Kadar Gula Darah pada Pasien Diabetes Melitus di Poliklinik Khusus Penyakit Dalam RSUP Dr. M. Djamil Padang Tahun 2015. KTI. Jurusan Gizi Politeknik Kesehatan Kemenkes Padang. Google Scholar

Widiyoga, R. C., Saichudin, S., \& Andiana, O. (2020). Hubungan Tingkat Pengetahuan tentang Penyakit Diabetes Melitus pada Penderita terhadap Pengaturan Pola Makan dan Physical Activity. Sport Science and Health, 2(2), 152-161. Google Scholar

\section{First publication right: \\ Jurnal Syntax Fusion: Jurnal Nasional Indonesia}

This article is licensed under:

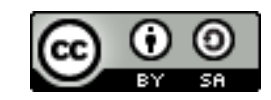

